\section{Pretransplant Watermelon Nutrition with Various Nitrate : Ammonium Ratios and Supplemental Calcium}

\author{
M.J. Lamb ${ }^{1}$, G.H. Clough ${ }^{2}$, and D.D. Hemphill, Jr. ${ }^{3}$ \\ Department of Horticulture, Oregon State University, Corvallis, OR 97331
}

Additional index words. Citrullus lanatus, pretransplant nutrition

\begin{abstract}
Watermelon [Citrullus lanatus (Thunb.) Matsum. and Nakai 'Crimson Sweet'] was seeded in a commercial peat medium in multicell containers. Five $\mathrm{NO}_{3}: \mathrm{NH}_{4}$ ratios and five levels of supplemental Ca were combined factorially in a $100 \mathrm{~N}-31 \mathrm{P}-265 \mathrm{~K} \mathrm{mg} \cdot \mathrm{liter}^{-1}$ pretransplant nutrition regime. The medium was amended with $\mathrm{CaCO}_{3}$ in 1989; the medium was not amended in 1990. Dry-matter accumulation had decreased with increasing $\mathrm{NH}_{4}-\mathrm{N} 3$ weeks after seeding both years. In 1989, increasing $\mathrm{NH}_{4}-\mathrm{N}$ also had decreased seedling growth by the last sampling date due to decreased $\mathrm{NH}_{4}^{+}$uptake. Shoot $\mathrm{N}$ concentration was higher in 1990 than 1989, but $\mathrm{N}$ uptake was similar. On the first sampling date in both years, increasing the Ca concentration decreased seedling growth and increased medium electrical conductivity (EC). In 1990, increasing the Ca concentration raised shoot $\mathbf{N}$ concentration but did not increase seedling growth or $\mathbf{N}$ uptake. Either $\mathbf{N}$ form at 100 $\mathrm{mg} \mathrm{N} /$ liter and Ca at 4 to $8 \mathrm{mmol} \cdot \mathrm{Cl}^{-1}{ }^{-1}$ were optimal for watermelon transplant production, but $\mathrm{Ca}$ at $>8 \mathrm{mmol} \cdot \mathrm{liter}^{-1}$ suppressed transplant growth.
\end{abstract}

Pretransplant nutritional conditioning (PNC) has been shown to influence transplant quality, seedling establishment, and yield for some crops (Adler et al., 1984; Dufault, 1985, 1986; Tremblay and Gosselin, 1989a, 1989b; Weston and Zandstra, 1989). Several studies have shown the importance of $\mathrm{N}$ rate in the PNCregime (Adleretal., 1984; Dufault, 1985, 1986), but $\mathrm{N}$ form in the regime has received less attention (Tremblay and Gosselin, 1989a, 1989b).

Ammonium- $\mathrm{N}$ as the predominant $\mathrm{N}$ source in fertilization regimes can be detrimental (Alan, 1989). Ammonium acidifies rhizospheric $\mathrm{pH}$ and depresses the uptake of other important cations (Alan, 1989; Barker and Maynard, 1972). Ammonium toxicity is ameliorated in media with a high $\mathrm{pH}$-buffer capacity near pH 7.0 (Barker et al., 1966a, 1966b). Adding Ca to $\mathrm{NH}_{4}-\mathrm{N}$-based fertilizers decreases $\mathrm{NH}_{3}$ volatilization (Fenn and Matocha, 1981; Fenn and Taylor, 1981), alleviates $\mathrm{NH}_{4}-\mathrm{N}$ toxicity symptoms, and produces a synergistic plant growth response in calcareous and noncalcareous media (Fenn et al., 1987).

Recommended $\mathrm{N}$ sources for soilless media and hydroponic production contain $\mathrm{NO}_{3}-\mathrm{N}$ (Lorenz and Maynard, 1980). Since typical

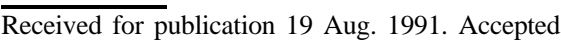
for publication 21 Sept. 1992. The cost of publishing this paper was defrayed in part by the payment of page charges. Under postal regulations, this paper therefore must be hereby marked advertisement solely to indicate this fact.

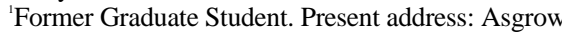
Seed Co., Box 667, Rockpile Rd., Arvin, CA 932030667.

${ }^{2}$ Hermiston Agricultural Research and Extension Center, Box 105, Hermiston, OR 97838.

${ }^{3}$ North Willamette Research and Extension Center, 15210 NE Wiley Rd., Aurora, OR 97002. only.

${ }^{2}$ Mean of 20 eight-plant samples.

${ }^{\mathrm{Y}}$ Mean of 160 plants. mouth, Minn.) using Fisons Sunshine Mix \#3 (76\% sphagnum peat, $24 \%$ fine vermiculite, dolomitic limestone, light nutrient charge, wetting agent; Fisons Western, Downers Grove, Ill.) on 17 July 1989 and 16 Apr. 1990. After being leached with tap water [3N-1P$7 \mathrm{~K}$ (mg.liter $\left.{ }^{-1}\right), \mathrm{pH} 7.8$, electrical conductivity (EC) $\left.0.3 \mathrm{dS} \cdot \mathrm{m}^{-1}\right]$, the medium contained low nutrient levels [6N-1P-7K $\left(\mathrm{mg} \cdot \mathrm{liter}^{-1}\right)$, $\mathrm{pH} 7.8$, EC $0.37 \mathrm{dS} \cdot \mathrm{m}^{-1}$ ]. In 1989 only, $\mathrm{CaCO}_{3}$ was added to the medium at $10 \%(\mathrm{w} / \mathrm{v})$. Treatments consisted of $100 \mathrm{~N}-31 \mathrm{P}-265 \mathrm{~K}$ (mg-liter ${ }^{-1}$ ) solutions having one of five $\mathrm{NO}_{3}: \mathrm{NH}_{4}$ ratios $(100: 0,75: 25,50: 50,25: 75$, or $0: 100)$ and one of five levels of supplemental Ca $(0,4,8,12$, or $16 \mathrm{~mm}$ from $\mathrm{CaCl}_{2}$ ) in factorial combination. Concentrations of $\mathrm{N}, \mathrm{P}$ (from $\mathrm{H}_{3} \mathrm{PO}_{4}$ ), and $\mathrm{K}$ (from $\mathrm{KCl}$ ) remained constant for all treatments. Solutions were prepared using tap water; its $\mathrm{N}$ content $\left(\mathrm{NO}_{3}-\mathrm{N}\right)$ was not figured into the calculations. Treatment solution $\mathrm{pH}$ ranged from 6.1 (100 mg NH$-\mathrm{N} /$ liter) to $6.4(100 \mathrm{mg}$ $\mathrm{NO}_{3}$-N/liter). Treatments were applied to runoff 6 days-week ${ }^{-1}$ and began 1 week after seeding. Three weeks after seeding, treatment frequency was reduced to once every other day. Treatment application frequency was reduced in the last week to simulate the commercial practice of reducing fertilizer application to harden seedlings before transplanting. In 1989, the medium was leached with tap water between application days during the last week to reduce seedling growth. Daily canopy temperature in the double-polyethylene-covered greenhouse at Hermiston, Ore., averaged 35C in 1989 and 25C in 1990.

The experiment was designed as a randomized complete block with four replications of one 72-cell tray per replicate. Samples consisted of eight plants taken from each 72-cell

Table 1. Nitrate : ammonium ratio effect on shoot dry weight, leaf area, plant height, and shoot $\mathrm{N}$ content of watermelon seedlings. The growing medium was supplemented with $\mathrm{CaCO}_{3}$ at $10 \%(\mathrm{w} / \mathrm{v})$ in 1989

\begin{tabular}{|c|c|c|c|c|c|c|c|}
\hline \multirow{3}{*}{$\begin{array}{l}\mathrm{NO}_{3}: \mathrm{NH}_{4} \\
\text { ratio }\end{array}$} & \multicolumn{2}{|c|}{ Dry $w^{2}(g)$} & \multicolumn{2}{|c|}{ Leaf area $\left(\mathrm{cm}^{2}\right)$} & \multirow{3}{*}{$\begin{array}{l}\text { Plant ht } \\
\text { (cm) }\end{array}$} & \multicolumn{2}{|c|}{$\mathbf{N}$} \\
\hline & \multicolumn{4}{|c|}{ Time after seeding (weeks) } & & \multirow{2}{*}{$\begin{array}{c}\text { Concn } \\
\text { (\% dry wt) }\end{array}$} & \multirow{2}{*}{$\begin{array}{c}\text { Uptake } \\
\text { (mg) }\end{array}$} \\
\hline & 3 & 4 & 3 & 4 & & & \\
\hline \multicolumn{8}{|c|}{1989} \\
\hline $100: 0$ & 2.69 & 5.47 & 372 & 517 & 14.6 & 1.64 & 90 \\
\hline $75: 25$ & 2.63 & 4.96 & 360 & 470 & 14.5 & 1.65 & 82 \\
\hline $50: 50$ & 2.61 & 4.91 & 373 & 465 & 14.5 & 1.53 & 75 \\
\hline $25: 75$ & 2.55 & 5.12 & 371 & 491 & 14.6 & 1.64 & 84 \\
\hline $0: 100$ & 2.51 & 4.72 & 339 & 464 & 14.6 & 1.54 & 73 \\
\hline \multicolumn{8}{|l|}{ Contrasts } \\
\hline 100:0 vs, others & $* * *$ & $* * *$ & NS & * & NS & NS & ** \\
\hline$>50: 50$ vs. others & $* * *$ & $* *$ & NS & NS & NS & * & ** \\
\hline$<50: 50$ vs. others & $* * *$ & NS & NS & NS & NS & NS & NS \\
\hline $0: 100$ vs. others & $* * *$ & $* *$ & $* *$ & NS & NS & NS & ** \\
\hline \multicolumn{8}{|c|}{1990} \\
\hline 100:0 & 2.10 & 3.92 & 182 & 324 & 12.3 & 2.24 & 87 \\
\hline $75: 25$ & 2.05 & 3.94 & 180 & 314 & 11.9 & 2.08 & 82 \\
\hline $50: 50$ & 2.00 & 3.93 & 180 & 321 & 11.9 & 2.16 & 85 \\
\hline $25: 75$ & 1.92 & 3.82 & 183 & 320 & 11.3 & 2.24 & 86 \\
\hline $0: 100$ & 1.81 & 3.83 & 182 & 357 & 12.1 & 2.36 & 90 \\
\hline \multicolumn{8}{|l|}{ Contrasts } \\
\hline $100: 0$ vs. others & $* * *$ & NS & NS & NS & $* * *$ & NS & NS \\
\hline$>50: 50$ vs. others & $* * *$ & NS & NS & $*$ & $* * *$ & $* * *$ & NS \\
\hline$<50: 50$ vs. others & $* * *$ & NS & NS & $* *$ & $* * *$ & $* * *$ & $*$ \\
\hline $0: 100$ vs. others & $* * *$ & NS & NS & $* * *$ & $* * *$ & $* * * *$ & $* *$ \\
\hline
\end{tabular}

ss $, * * *, * * *$ Nonsignificant or significant at $P=0.05,0.01$, or 0.001 , respectively. 
Table 2. Nitrate: ammonium ratio effect on medium solution $\mathrm{EC}$ and $\mathrm{pH} 3$ weeks after seeding.

\begin{tabular}{lccccc}
\hline $\mathrm{NO}_{3}: \mathrm{NH}_{4}$ & \multicolumn{2}{c}{1989} & & \multicolumn{2}{c}{1990} \\
\cline { 2 - 3 } \cline { 6 - 7 } ratio & $\mathrm{EC}$ & $\mathrm{pH}$ & & $\mathrm{EC}$ & $\mathrm{pH}$ \\
\hline $100: 0$ & $0.88^{\mathrm{z}}$ & 8.08 & & 2.20 & 7.18 \\
$75: 25$ & 0.92 & 7.92 & & 2.45 & 6.70 \\
$50: 50$ & 1.01 & 7.85 & & 2.75 & 6.36 \\
$25: 75$ & 1.02 & 7.70 & & 3.25 & 6.17 \\
$0: 100$ & 1.12 & 7.67 & & 3.26 & 6.05 \\
$\mathrm{~N} \times \mathrm{Ca}$ & $\mathrm{NS}$ & $\mathrm{NS}$ & & $\mathrm{NS}$ & $* * *$ \\
$100: 0$ vs. others & $\mathrm{NS}$ & $* * *$ & & $* * *$ & $* * *$ \\
$>50: 50$ vs. others & $*$ & $* * *$ & & $* * *$ & $* * *$ \\
$<50: 50$ vs. others & $*$ & $* * *$ & & $* * *$ & $* * *$ \\
$0: 100$ vs. others & $*$ & $* * *$ & & $* * *$ & $* * *$ \\
\hline
\end{tabular}

${ }^{\mathrm{z}}$ Mean of 20 eight-plug samples.

${ }^{\text {Ns, }, * * * *}$ Nonsignificant or significant at $P=0.05$ or 0.001 , respectively.

tray replicate. Statistical Analysis System (SAS) PROC GLM was used to separate treatment effects using single-degree-offreedom orthogonal contrasts for the $\mathrm{NO}_{3}: \mathrm{NH}_{4}$ ratio main effect (SAS Inst., Cary, N.C.). Linear, quadratic, and cubic contrasts were used to analyze $\mathrm{Ca}$ main effect.

Medium $\mathrm{pH}$ and EC were determined 21 days after seeding. Medium extracts for measuring $\mathrm{pH}$ and EC were prepared using the saturated media extraction method of Warnke (1986). Plant dry weight and leaf area were measured 21 and 28 days after seeding. Leaves were removed from petioles before measuring area (LI-COR 3000; LI-COR, Lincoln, Neb.). Seedlings were excised at soil level, and plant height was measured at 28 days. Plant samples were dried in a forced-air oven at $65 \mathrm{C}$ for $24 \mathrm{~h}$ and ground in a Wiley mill to pass through a screen with 0.425-mmpores (Lockman, 1980). Total $\mathrm{N}$ was determined by acid digestion of 0.4-g subsamples. Diluted digests were analyzed using an Alpkem rapid-flow analyzer at the Oregon State Univ. Plant Analysis Laboratory, Corvallis (Gaines and Mitchell, 1979).

$\mathrm{NO}_{3}: \mathrm{NO}_{4}$ ratio. In 1989 , shoot dry weights decreased with decreasing $\mathrm{NO}_{3}: \mathrm{NH}_{4}$ ratio at 3 and 4 weeks after seeding (Table 1). Leaf area was reduced with $100 \% \mathrm{NH}_{4}-\mathrm{N}$ at 3 weeks; $100 \% \mathrm{NO}_{3}-\mathrm{N}$ produced the largest leaf area at 4 weeks. Plant height was not affected by the ratio. Shoot $\mathrm{N}$ accumulation was highest with $\mathrm{NO}_{3}-\mathrm{N}$ as the predominant $\mathrm{N}$ form.

In 1990, shoot dry weights decreased with decreasing $\mathrm{NO}_{3}$ : $\mathrm{NH}_{4}$ ratio at 3 weeks; however, at 4 weeks shoot dry weight was not affected. Leaf area was similar for all $\mathrm{N}$-form ratios at week 3, but increased as the $\mathrm{NH}_{4}-\mathrm{N}$ proportion increased from $25 \%$ to $100 \%$ at week 4. Seedlings grew tallest with either $100 \% \mathrm{NO}_{3}-\mathrm{N}$ or $100 \% \mathrm{NH}_{4}-\mathrm{N}$. Nitrogen concentration and accumulation were highest with $75 \%$ to $100 \% \mathrm{NH}_{4}-\mathrm{N}$.

In 1989, seedling shoot dry weight was higher, leaf area was larger, and plants were taller than in 1990. Nitrogen accumulation was similar each year, but $\mathrm{N}$ concentration was $<2 \%$ for all treatments in 1989, thus indicating a possible $\mathrm{N}$ deficiency. Reduced shoot $\mathrm{N}$ content with increasing $\mathrm{NH}_{4}-\mathrm{N}$ in 1989 may have been induced by loss of available $\mathrm{NH}_{4}^{+}$, a decrease in $\mathrm{NH}_{4}^{+}$uptake, or reduced transport of assimilated or free $\mathrm{NH}_{4}^{+}$to the shoots. Daily greenhouse maxima ranged from 29.5 to $43 \mathrm{C}$ in 1989 and from 23.5 to $27 \mathrm{C}$ in 1990. Higher temperatures may explain why plants grew larger in 1989 than in 1990. A 10C increase in temperature may raise rates of ion uptake, respiration, and enzymatic reactions by more than a factor of 2 (Marschner, 1986). The increased growth may have diluted the $\mathrm{N}$ concentration, since tissue $\mathrm{N}$ concentration was lower in 1989.

In both years, medium EC increased with increasing proportion of $\mathrm{NH}_{4}-\mathrm{N}$ at 3 weeks after seeding (Table 2). As medium EC increased, shoot dry weight decreased with more $\mathrm{NH}_{4}-\mathrm{N}$ in the $\mathrm{NO}_{3}: \mathrm{NH}_{4}$ ratio. Although medium EC was not measured later than week 3 , we assumed that EC decreased over all treatments as frequency of applications decreased, and trays were leached after week 3 in 1989. Watermelon is moderately sensitive to increasing soil salinity, and growth decreased at a saturated extract EC $>1.5 \mathrm{dS} \cdot \mathrm{m}^{-1}$ (Maas, 1986). In 1989, medium EC did not exceed 1.20 $\mathrm{dS} \cdot \mathrm{m}^{-1}$. However, high temperatures in 1989 may have increased transpiration, which can cause solute accumulation in the rhizosphere (Marschner, 1986). Water potential in the rhizosphere could have decreased due to increased osmotic potential, thus reducing plant growth. EC measurements on medium solution extracts from the entire medium volume and not on the rhizosphere solution may not accurately reflect rhizosphere salinity. Medium EC was lower in 1989 than 1990, possibly due to increased ion uptake associated with greater dry matter accumulation.

Medium solution $\mathrm{pH}$ decreased in both years with increasing $\mathrm{NH}_{4}-\mathrm{N}$ (Table 2). Hydrogen ion extrusion into the soil solution caused by $\mathrm{NH}_{4}^{+}$uptake decreases medium $\mathrm{pH}$ (Barker et al., 1966a, 1966b). Also, $\mathrm{NH}_{4}^{+}$may have depressed medium $\mathrm{pH}$ by displacing $\mathrm{H}^{+}$ on the medium cation exchange complex (Bunt, 1976).

High temperatures and high soil solution $\mathrm{pH}$ are conducive to ammonia volatilization from $\mathrm{NH}_{4}-\mathrm{N}$-based fertilizers (Fenn and Kissel, 1973, 1974). Barker et al. (1966b) reported a

Table 3. Supplemental Ca effect on shoot dry weight, leaf area, stem length, and shoot $\mathrm{N}$ content of watermelon seedlings. The growing medium was supplemented with $\mathrm{CaCO}_{3}$ at $10 \%(\mathrm{w} / \mathrm{v})$ in 1989 only.

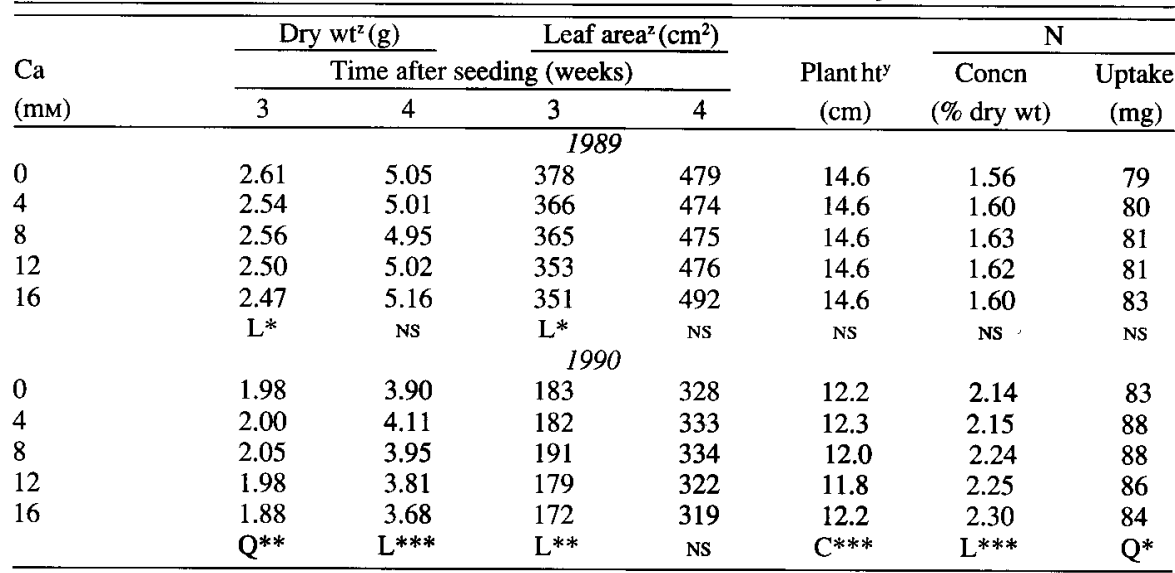

${ }^{x}$ Mean of 20 eight-plant samples.

${ }^{y}$ Mean of 160 plants.

Ns,*******Nonsignificant or significant at $P=0.05,0.01$, or 0.001 , respectively. $\mathrm{L}$, linear; $\mathrm{Q}$, quadratic; $\mathrm{C}$, cubic. lower $\mathrm{N}$ content in bean (Phaseolus vulgaris L.) leaves with $\mathrm{NH}_{4}-\mathrm{N}$ fertilization, which increased root environment $\mathrm{pH}$ from 4.5 to 8.5. This alkalinity decreased free $\mathrm{NH}, '$, amide, and amino acid $\mathrm{N}$ fractions in bean leaves, but not in roots. In our study, $\mathrm{pH}$ decreased with increasing $\mathrm{NH}_{4}-\mathrm{N}$, the effect of $\mathrm{N}$ form on $\mathrm{N}$ accumulation most likely was attributable to excess soluble salts (EC) with $\mathrm{NH}_{4}$ fertilization rather than to a $\mathrm{pH}$ effect.

Adding $\mathrm{CaCO}_{3}$ to the medium raised extract $\mathrm{pH}$ in 1989 higher than in 1990.

Nitrogen application rate was $\approx 33 \%$ of the amount recommended in Hoagland's solution 1 and 2 (Lorenz and Maynard, 1980). Although $\mathrm{N}$ rate was reduced, higher greenhouse temperatures induced excessive shoot growth in 1989. In 1990, plant growth was slower, and N was not deficient. Based on these results, NO,$\mathrm{N}$ or $\mathrm{NH}_{4}-\mathrm{N}$ at $100 \mathrm{mg} \cdot \mathrm{liter}^{-1}$ is adequate for watermelon transplant production. Transplant size is an important consideration for the transplant nursery and the grower. Large transplants are difficult to handle and may be seriously damaged during mechanical transplanting. Excessive $\mathrm{N}$ in the PNC could produce large, unwieldy transplants and increase $\mathrm{N}$ content of wastewater.

Similar seedling growth resulted with either form of $\mathrm{N}$ at $100 \mathrm{mg} \mathrm{N} /$ liter. No detrimental effects usually associated with $\mathrm{NH}_{4}-\mathrm{N}$ were evident in either year. Our results concur with the findings of Barker and Maynard (1972) and Kirkby (1968) that growth with $\mathrm{NH}_{4}-\mathrm{N}$ was slightly lower than, or similar to, that with $\mathrm{NO}_{3}-\mathrm{N}$ in a medium buffered near $\mathrm{pH}$ 7.0.

The interaction between supplemental $\mathrm{Ca}$ (from $\mathrm{CaCl}_{2}$ ) and $\mathrm{NH}_{4}-\mathrm{N}$ on shoot $\mathrm{N}$ content and growth was not significant in 1989; therefore, $\mathrm{CaCO}_{3}$ was not added to the medium in 1990. The $\mathrm{CaCO}_{3}$ amendment may have resulted in solubilized $\mathrm{Ca}$ levels in the medium above the maximum $\mathrm{Ca}$ level of $10 \mathrm{mmol} \cdot$ liter $^{-1}$ reported by Fenn et al. (1987) for synergistic plant growth response with $\mathrm{NH}_{4}-\mathrm{N}$.

Supplemental Ca. Adding $\mathrm{Ca}$ to the PNC regimes affected seedling growth more in 1990 
Table 4. Supplemental Ca effect on medium solution $\mathrm{EC}$ and $\mathrm{pH} 3$ weeks after seeding.

\begin{tabular}{lccccc}
\hline \hline Ca & \multicolumn{2}{c}{1989} & & \multicolumn{2}{c}{1990} \\
\cline { 2 - 3 } \cline { 5 - 6 }$(\mathrm{mM})$ & $\mathrm{EC}$ & $\mathrm{pH}$ & & $\mathrm{EC}$ & $\mathrm{pH}$ \\
\hline 0 & 0.70 & 8.06 & & 1.40 & 6.77 \\
4 & 0.79 & 7.96 & & 1.94 & 6.59 \\
8 & 1.03 & 7.76 & & 2.76 & 6.45 \\
12 & 1.25 & 7.71 & & 3.46 & 6.36 \\
16 & 1.18 & 7.73 & & 4.35 & 6.30 \\
& $\mathrm{C}^{*}$ & $\mathrm{Q}^{* * *}$ & & $\mathrm{~L}^{*}$ & $* * *$ \\
$\mathrm{~N} \times \mathrm{Ca}$ & $\mathrm{NS}$ & NS & & NS & $* * *$ \\
\hline
\end{tabular}

${ }^{2}$ Mean of 20 eight-plug samples.

ms,,$+*+$ Nonsignificant or significant at $P=0.05$ or

0.001 , respectively. $L$, linear; $Q$, quadratic; $C$, cubic.

than in 1989 (Table 3). In 1989, at week 3, shoot dry weight and leaf area decreased linearly with increasing $\mathrm{Ca}$. Leaching the medium 3 weeks after seeding may have negated any response to increased $\mathrm{Ca}$ at week 4 . Differences in dry weight in 1989 may have been enhanced with higher $\mathrm{Ca}$ levels from the $\mathrm{CaCO}_{3}$ amendment. Fenn et al. (1987) measured 5 mmol $\mathrm{Ca} /$ liter solubilized by $\mathrm{NH}_{4}^{+}$uptake in a quartz sand amended with $\mathrm{CaCO}_{3}$ at $1 \%$ (w/ w).

In 1990, dry weight responded quadratically and leaf area decreased linearly. Shoot dry weight was highest and leaf area largest with $\mathrm{Ca}$ at $4 \mathrm{mmol} \cdot$ liter $^{-1}$, while plant height respondednonlinearly withincreasing $\mathrm{Ca}$. The shortest plants were obtained with $12 \mathrm{mmol}$ $\mathrm{Ca} /$ liter.

Increasing $\mathrm{Ca}$ did not affect shoot $\mathrm{N}$ concentration and accumulation in 1989. However, in 1990, shoot $\mathrm{N}$ concentration increased linearly with increasing $\mathrm{Ca}$. Shoot dry weight production per milligram of $\mathrm{N}$ decreased as $\mathrm{Ca}$ level increased. As $\mathrm{Ca}$ rate increased, less shoot dry matter was produced; $\mathrm{N}$ uptake, however, did not decrease at the same rate. This affected $\mathrm{N}$ concentration.

In both years at week 3 , as Ca increased, medium EC increased (Table 4). Medium EC may have decreased 4 weeks after seeding due to medium leaching in 1989 and reduced treatment application frequency after week 3 in both years, producing variable growth from week 3 to 4 (Table 3). In 1989, as Ca level increased, medium $\mathrm{pH}$ decreased. In 1990, N form and $\mathrm{Ca}$ interacted to affect medium $\mathrm{pH}$ (Table 5). Within each Ca level, $\mathrm{pH}$ decreased as the $\mathrm{NO}_{3}: \mathrm{NH}_{4}$ ratio decreased. Within each $\mathrm{NO}_{3}$ : $\mathrm{NH}_{4}$ ratio, increasing levels of $\mathrm{Ca}$ also decreased medium $\mathrm{pH}$. However, at $\mathrm{NO}_{3}: \mathrm{NH}_{4}$ ratios $>50: 50$, the decrease was quadratic; at $\leq 50: 50$, the effect was linear. Ammonium-N uptake acidifies rhizosphere $\mathrm{pH}$, while $\mathrm{NO}_{3}-\mathrm{N}$ increases rhizosphere $\mathrm{pH}$ (Alan, 1989; Barker
Table 5. Medium $\mathrm{pH}$ as affected by interaction of supplemental $\mathrm{Ca}$ and $\mathrm{NO}_{3}: \mathrm{NH}_{4}$ ratio, 1990.

\begin{tabular}{lccccc}
\hline $\mathrm{Ca}$ & \multicolumn{5}{c}{$\mathrm{NO}_{3}: \mathrm{NH}_{4}$ ratio } \\
\cline { 2 - 6 }$(\mathrm{mM})$ & $100: 0$ & $75: 25$ & $50: 50$ & $25: 75$ & $0: 100$ \\
\hline 0 & 7.65 & 6.96 & 6.61 & 6.34 & 6.27 \\
4 & 7.32 & 6.78 & 6.47 & 6.30 & 6.11 \\
8 & 7.08 & 6.66 & 6.32 & 6.14 & 6.05 \\
12 & 6.96 & 6.59 & 6.22 & 6.09 & 5.93 \\
16 & 6.89 & 6.53 & 6.18 & 6.00 & 5.92 \\
& $\mathrm{Q}^{* *}$ & $\mathrm{Q}^{* * *}$ & $\mathrm{~L}^{* * *}$ & $\mathrm{~L}^{* * *}$ & $\mathrm{~L}^{* * *}$ \\
\hline
\end{tabular}

**,**+* Significant at $P=0.01$ or 0.001 , respectively. $\mathrm{L}$, linear; $Q$, quadratic.

and Maynard, 1972). Cations displace $\mathrm{H}^{+}$on the peat exchange complex, thus decreasing rhizosphere $\mathrm{pH}$ (Bunt, 1976). Calcium and $\mathrm{NH}_{4}-\mathrm{N}$ together decreased medium $\mathrm{pH}$. Nitrate uptake $(\mathrm{OH}-$ extrusion) buffered acidity at $\mathrm{pH}$ values above those of treatments with $\mathrm{NH}_{4}-\mathrm{N}$ as the predominant $\mathrm{N}$ form.

The synergistic effect of supplemental $\mathrm{Ca}$ on $\mathrm{NH}_{4}-\mathrm{N}$ nutrition as reported by Fenn et al. (1987) was not detected in our study.

Increasing $\mathrm{Ca}$ influenced watermelon seedling growth by increasing medium solution EC. In this study, Ca at 4 to $8 \mathrm{mmol} \cdot$ liter $^{-1}$ was optimal for transplant production based on shoot growth and shoot $\mathrm{N}$ content. However, $\mathrm{Ca}$ at 12 to $16 \mathrm{mmol} \cdot$ liter $^{-1}$ suppressed seedling growth without adversely affecting $\mathrm{N}$ uptake. Based on these results, either $\mathrm{NO}_{3}-\mathrm{N}$ or $\mathrm{NH}_{4}-\mathrm{N}$ at $100 \mathrm{mg} \mathrm{N} /$ liter is recommended for watermelon transplant production.

\section{Literature Cited}

Adler, P.R., R.J. Dufault, and L. Waters, Jr. 1984. Influence of nitrogen, phosphorous and potassium on asparagus transplant quality. HortScience 19:565-566.

Alan, R. 1989. The effect of nitrogen nutrition on growth, chemical composition and response of cucumbers (Cucumis sativus L.) to nitrogen forms in solution culture. J. Hort. Sci. 64:467474.

Barker, A.V. and D.N. Maynard. 1972. Cation and nitrate accumulation in pea and cucumber plants as influenced by nitrogen nutrition. J. Amer. Soc. Hort. Sci. 97:27-30.

Barker, A.V., R.J. Volk, and W.A. Jackson. 1966a. Growth and nitrogen distribution patterns in bean plants (Phaseolus vulgaris L.) subjected to ammonium nutrition: I. Effects of carbonates and acidity control. Soil Sci. Soc. Amer. Proc. 30:228-232.

Barker,A.V.,R.J. Volk, and W.A. Jackson. 1966b. Root environment acidity as a regulatory factor in ammonium assimilation by the bean plant. Plant Physiol. 41:1193-1199.
Bunt, A.C. 1976. Modem potting composts. The Pennsylvania State Univ. Press, Pittsburgh.

Dufault, R.J. 1985. Relationship among nitrogen, phosphorous, and potassium fertility regimes on celery transplant growth. HortScience 20: 1104 1106.

Dufault, R.J. 1986. Influence of nutritional conditioning on muskmelon transplant quality and yield. J. Amer. Soc. Hort. Sci. 111:698-703.

Fenn, L.B. and D.E. Kissel. 1973. Ammonia volatilization from surface applications of ammonium compounds on calcareous soils: I. General theory. Soil Sci. Soc. Amer. Proc. 37:855-859.

Fenn, L.B. and D.E. Kissel. 1974. Ammonia volatilization from surface applications of ammonium compounds on calcareous soils: II. Effect of temperature and rate of ammonium nitrogen application. Soil Sci. Soc. Amer. Proc. 38:606610.

Fenn, L.B. and J.E. Matocha. 1981.Ammonialosses from surface applied urea and ammonium fertilizers as influenced by rate of soluble calcium. Soil Sci. Soc. Amer. Proc. 45:883-886.

Fenn, L.B. and R.M. Taylor. 1981. Ammonialosses from surface applied nitrogen fertilizer as controlled by soluble calcium and magnesium: General theory. Soil Sci. Soc. Amer. Proc. 45:777-781.

Fenn, L.B., R.M. Taylor, and G.L. Horst. 1987. Phaseolus vulgaris growth in an ammonium based nutrient solution with variable calcium. Agron. J. 79:89-91.

Gaines, T.P and G.A. Mitchell. 1979. Chemical methods for soil and plant analysis. Univ. of Georgia Coastal Plain Expt. Sta. Agron. Hndbk. 1.

Kirkby, E.A. 1968. Influence of ammonium and nitrate nutrition on the cation-anion balance and nitrogen and carbohydrate metabolism of white mustard plants grown in dilute nutrient solutions. Soil Sci. 105:133-141.

Lockman, R.B. 1980. Review of soil and plant tissue preparation procedures. J. Assn. Offic. Anal. Chem. 63:766-769.

Lorenz, O.A. and D.N. Maynard. 1980. Knott's handbook for vegetable growers. Wiley, New York.

Maas, E.V. 1986. Salt tolerance of plants. Applied Agr. Res. 1:12-26.

Marschner, H. 1986. Mineral nutrition of higher plants. Academic, New York.

Tremblay, N. and A. Gosselin. 1989a. Growth and nutrient status of celery seedlings in response to nitrogen fertilization and $\mathrm{NO}$, $\mathrm{NH}$, ratio. HortScience 24:284-288.

Tremblay, N. and A. Gosselin. 1989b. Growth, nutrient status, and yield of celery seedlings in response to urea fertilization. HortScience 24:288-291.

Warnke, D.D. 1986. Analyzing greenhouse growth media by the saturation extraction method. HortScience 21:223-225.

Weston, L.A. and B.H. Zandstra. 1989. Transplant age and $\mathrm{N}$ and $\mathrm{P}$ nutrition effects on growth and yield of tomatoes. HortScience 24:88-90. 